\title{
WestVirginiaUniversity.
}

Department of Economics

Working Paper Series

\section{Bank Branching Deregulation and High School Graduation}

Patrick Reilly

Working Paper No. 16-29

This paper can be found at the College of Business and Economics Working Paper Series homepage: 


\title{
Bank Branching Deregulation and High School Graduation
}

\author{
Patrick Reilly \\ Department of Economics \\ West Virginia University
}

This Version: December 22, 2016

\begin{abstract}
:
This paper utilizes variation in timing of deregulation to investigate the relationship between bank branching deregulation and educational outcomes for individuals in 39 states over the period 1977 - 1999. In order to investigate the labor market channel, this paper focuses on the relationship between deregulation and high school graduation, as opposed to recent studies focusing on the relationship between deregulation and college attendance via the credit market channel. Results indicate increases in the likelihood of graduating high school after deregulation. Results also suggest heterogeneity in effects due to race and age at deregulation. Finally, models testing the relationship between bank deregulation and post-secondary education outcomes generate similar results to findings from previous studies.
\end{abstract}

Keywords: Bank branching, education, bank deregulation

JEL Codes: G21, G28, I21, I24, J24 


\section{Introduction}

Most states initiated intrastate branching deregulation of commercial banks over the period 1970 to 1994, culminating in the Riegle-Neal Act. Several issues influenced deregulation: low profits for small commercial banks caused by usury laws acting as interest rate ceilings during a time of high nominal interest rates, and higher profits from larger banks due to banking innovations such as the Automated Teller Machine (ATM). ${ }^{1}$

Deregulation allowed commercial banks to compete with geographically unconstrained money market mutual funds and increased the size of banks, allowing them to take advantage of economies of scale. Deregulation also decreased the market power of local banks by lowering barriers to entry. In the period after deregulation, banking costs decreased and competition among banks for depositors increased. Relaxing bank branching constraints should have reduced interest rates for loans, stimulating the economy.

Jayaratne and Strahan (1996) and Clarke (2004) find economic growth positively related to bank branching deregulation. In fact, the same deregulation is shown to have many real effects. Some effects are direct, for instance an increase in commercial banking industry competition (Stiroh and Strahan, 2003). Other effects have a more indirect link. As an example, Beck et al. (2010) find decreases in income inequality due to bank branching deregulation. This paper focuses on indirect consequences of bank branching deregulation on educational attainment.

Previously, both Levine and Rubinstein (2013) and Sun and Yannelis (2016) identified a relationship between bank branching deregulation and college enrollment. Both papers concluded that deregulation affected college enrollment through a credit channel by reducing credit constraints faced by individuals contemplating post-secondary education. Levine and Rubinstein focused on how intellectually able but financially constrained individuals were affected by deregulation. Sun and Yannelis concentrated on financial constraints, used multiple data sets, and found increases in both post-secondary school attendance, completion of postsecondary education, and college loans especially in low- and middle-income families.

\footnotetext{
${ }^{1}$ For a review of the political economy surrounding bank branching deregulation see Krozner and Strahan (1999) or Krozner and Strahan (2014).
} 
This paper examines a labor market channel as a path for deregulation to affect educational attainment by analyzing individuals' secondary education outcomes. Increased college enrollment is not necessarily indicative of labor market effects because, as Sun and Yannelis (2016) and Levine and Rubinstein (2013) found, credit markets acted as a channel from bank branching deregulation to college attendance. However, a credit market channel likely had a smaller, if any, effect on high school education as secondary school does not typically charge tuition.

Not only does focusing on high school graduation provide evidence for labor market effects; economically, policy impacts on high school graduation are at least as important as college attendance. ${ }^{2}$ First, high school diplomas are compulsory for college enrollment. Additionally, if individuals are more likely to attend college after deregulation, but fail to receive a degree, then they are likely worse off due to increased debt and forgone earnings. Finally, the negative consequences of failing to receive a high school diploma are far greater than the negative consequences of failing to attend college. Bridgeland et al. (2006) estimated the negative consequences of dropping out of high school, which included \$9,200 less income per year on average, greater rates of unemployment, and a smaller likelihood of reporting good health. Also, high school dropouts needed and received more public assistance than graduates. Oreopoulos (2007) reported similar findings.

With this in mind, focusing on high school graduation and earning college degrees instead of college attendance, a la Levine and Rubinstein (2013) or Sun and Yannelis (2016), provides a more comprehensive picture of the impact of bank branching deregulation on individual education decisions.

This paper estimates linear probability models explaining whether or not an individual achieved specific levels of education using data from the March Current Population Survey (CPS). A difference-in-differences approach utilizing variation in dates of state-level bank branching deregulation shows a positive impact of deregulation on secondary education outcomes. Deregulation is also associated with increases in post-secondary attendance and bachelor's degree achievement; these estimates are on par with results from Sun and Yannelis (2016) and 
Levine and Rubinstein (2013). The results suggest no significant heterogeneous effects of deregulation on educational attainment by gender. The results indicate race plays a factor as nonwhite individuals are not significantly affected. No heterogeneity is found over strictness of the original regulation. Deregulation affected younger individuals at higher rates for high school graduation and college degree achievement but had no effect on college attendance. This may indicate a short lived increase in supply of credit but a longer term influence on the labor market through human capital investment.

\section{Bank Branching Deregulation: Theoretical Effects}

\section{II.1: A short history of bank branching deregulation}

Deregulation of geographic bank branching restrictions is a widely analyzed policy change. Throughout the 1970s, 1980s, and 1990s most states removed geographic restrictions on bank branching. In 1969, 39 states had regulations on intrastate (within-state) branching and all 50 states had regulations on interstate (across-state) bank branching. By 1994, every state except Iowa had deregulated their intrastate branching in some form and only Hawaii continued to prohibit interstate bank branching. ${ }^{3}$

Why did restrictions on bank branching? One reason comes from the rent seeking/rent extraction literature. Taxes on bank profits were originally a large part of states' revenues (Sylla et al., 1987). To maximize revenue, states maximized bank profits. States legally increased monopoly power by limiting competition. Spreading banks out geographically, especially in an era without electronic banking, allowed banks to set prices higher than competition would dictate.

Depositors and borrowers in the $18^{\text {th }}$ and $19^{\text {th }}$ and even $20^{\text {th }}$ centuries chose not to switch banks because of the high cost of locating and traveling to competing banks. Thus, the service of banking was price inelastic, and, to increase profits, banks charged more for loans and paid less to depositors without losing many clients. Thus, by restricting competition through limiting bank branching, banks maximized profits and states maximized revenues. ${ }^{4}$ This rent extraction relationship became less important overtime as state governments found alternative sources of

\footnotetext{
${ }^{3}$ Deregulation dates from Kroszner and Strahan (1999). See table 1.

${ }^{4}$ This relationship falls within the rent extraction literature a la McChesney (1987).
} 
revenue. Nevertheless, incumbent banks, if rent seeking existed, lobbied state governments to keep the laws intact in order to protect monopoly rents. ${ }^{5}$

Interstate regulations originated because, in order to charter in a state, a bank incorporated in that state must pay a fee; whereas, a bank incorporated in a different state need not pay (Kroszner and Strahan, 2014). Once again, regulations acted to maximize state revenue.

Kroszner and Strahan (1999) suggest that these rents decreased, particularly for small banks, in the 1970s and into the 1980s because of high nominal interest rates combined with the usury law ceiling for rates charged on commercial bank loans. Creation of demand deposit substitutes such as money market mutual funds also directly hurt small banks’ profits.

During the same time period, larger banks benefited from banking innovations that acted to increase returns to scale. ATMs, credit scores, and other improvements in information technology all benefited large banks disproportionately with respect to small banks. Larger banks also benefited from bank branching deregulation by reducing risk geographically and from economies of scale. In this political economy story, large banks eventually outbid the incumbent small banks and deregulation laws passed (Kroszner and Strahan (2014). ${ }^{6}$

Bank branching deregulation has three types discussed in the literature. First, intrastate deregulation through mergers and acquisitions, next full intrastate or de novo branching deregulation, and third, interstate deregulation. This paper focuses on the first type, mergers and acquisitions. Mergers and acquisitions allowed Multibank Holding Companies to consolidate their subsidiaries into branches of a single bank. ${ }^{7}$

\footnotetext{
${ }^{5}$ If states are no longer extracting, we can still expect some sort of rent seeking by incumbent banks $a$ la Tullock (1967) and Krueger (1974).

6 Some small commercial banks and thrifts initiated a last ditch loan scheme to cover their losses from high interest rates and regulation. Armed with deregulation and moral hazard created by federal insurance of many Savings and Loans, some Savings and Loans took on very risky assets to make back losses. The failure of these junk assets led directly to the Savings and Loan Crisis in the 1980s (Kroszner and Strahan, 2014; White, 1991).

${ }^{7}$ However, banks could not open up a branch anywhere after merger and acquisition branching deregulation. They had to acquire or merge with an existing bank in order to add branches. The ability to add non-preexisting branches was the last step of intrastate bank branch deregulation. This, de novo branching, completed the intrastate bank branch deregulation. The last type of bank branching deregulation discussed here is interstate bank branch deregulation. This allowed MBHCs to own banks in states other than where they were headquartered.
} 
After each deregulation, banks grew larger and spread their risk geographically. Geographic spread of risk decreased the likelihood of a bank failure due to economic weakness in a certain region of a state. Bank size can reduce costs through economies of scale. If banks pass on this cost saving to depositors and borrowers, then deregulation could have had a positive influence on real economic variables.

The use of merger and acquisition deregulation is common in the literature because it has the greatest effect on other real variables and a larger variation in deregulation years (Jayaratne and Strahan, 1996; Beck et al., 2010; Levine and Rubinstein, 2013). Table 1, using dates from Kroszner and Strahan (1999), presents the years of deregulation for each state.

\section{II.2: Credit Constraints, Labor Markets, and Education}

Bank branching deregulation could affect education decisions in two ways: First, by affecting the credit market; second, by indirectly influencing the labor market. If credit constraints are relaxed and if education is a normal good, then parents should make a greater investment in their child's education, along with young adults increasing investment in their own education. Additionally, relaxing geographic restrictions could influence the labor market by changing the relative wages and availability of jobs for dropouts, high school grads, college attendees, and college degree earners. The overall effect likely depends on both channels, but the labor market channel likely has a greater effect on high school graduation than the credit channel.

\section{A. Easing of Credit for Individuals: Effects on Education}

Research suggests that relaxing credit constraints should increase educational investment. Although, some studies contend the economic importance of this effect. By passing cost savings to their customers, bank branching deregulation reduces credit constraints for students and their families (Sun and Yannelis, 2016).

Related studies include Carneiro and Heckman (2002) who, using National Longitudinal Survey of Youth 1979 (NLSY79) data, suggested credit constraints have very little influence on college attendance. Rather, long term effects of family income on quality of education and better home environment shaping cognitive and social ability are more important in determining college enrollment. In a follow up paper, Belley and Lochner (2007), using NLSY 1997 (NLSY97) data, 
demonstrated an increasing importance of income, wealth, and credit availability in determining college attendance in the two decades since Carneiro and Heckman's sample.

Caucutt and Lochner (2011) found differences in educational investment in younger versus older students. They split parental investment on their child's education into 'early' (investment in young children) and 'late' (investment in adolescents). Caucutt and Lochner found short term effects of increases in borrowing limits such as more early investment in children's education and greater college graduation rates. Finally, Caucutt and Lochner provided evidence suggesting early childhood investment is of greater importance than later investment especially for subsidies. Without the early investment, the individual will be of lower ability and cannot take advantage of additional subsidies for later education, especially college.

Using a theory that melds both labor market and credit channels, Bedard (2001) demonstrated that when credit constraints are relaxed on high ability high school students (or their families) they can afford to signal those high abilities to employers by earning a post-secondary degree. If these high ability individuals earn a college degree with newfound credit supply, they lower the average (and expected) ability level of someone earning a high school diploma. ${ }^{8}$ If this is the case, employers will update their expectation of ability signaled by high school diploma earners.

This increased signaling precision limits the free riding of lower ability students on financiallyconstrained, high-ability students. Labor markets react by reducing the relative wage and employment opportunities given to high school aged workers. With these lower benefits, fewer individuals will graduate high school, especially low ability students who face the highest costs of graduating high school. Thus, eliminating bank regulation increases credit availability, increasing college achievement of high-ability, (formerly) financial-constrained individuals and reducing the number of low-ability individuals graduating high school through a signaling mechanism.

A less constrained credit market could also allow families to finance spending. This may result in adolescents not working as many hours. ${ }^{9}$ The ability to spend more time focused on school and less time working could benefit individuals in the classroom, increasing the likelihood of high

\footnotetext{
${ }^{8}$ Taking high ability individuals out of a population will lower the average ability of a population.

${ }^{9}$ Although, the increase in aggregate demand could also have labor market impacts by increasing the demand for part-time employment of adolescents.
} 
school graduation, especially in low income households. However, greater finance of spending could increase debt and perhaps bankrupt families. Thus, in the long run, some families may find it more difficult to borrow for college when credit constraints are relaxed.

\section{B. Easing of Credit for Employers: Effect on Labor Market Conditions}

Labor market changes can affect educational attainment as the earnings from the labor market is a main opportunity cost of education. Bank branching deregulation is linked to labor market outcomes. Benmelech et al. (2011) and Beck et al. (2010) found decreases in unemployment rates following deregulation. Boustanifar's (2014) results also demonstrated a positive association between deregulation and employment growth.

As opportunity cost of education increases we expect some effect on educational attainment from deregulations through a labor market channel. The sign and magnitude of the effect depend on the relative changes in the labor market for workers of different skill levels. For instance, if only high skilled jobs increased wages due to branching deregulation, then individuals should tend to increase educational attainment in order to earn heightened wages. If only low skilled jobs gained wages from deregulation, then marginal individuals will choose to forgo education to start working at those low skilled jobs.

Researchers have demonstrated changes in labor markets generate measurable effects on educational attendance and completion. Black et al. (2005) studied how changes in labor markets, specifically, a coal boom in the 1970s and subsequent bust in the 1980s, caused changes in high school enrollment decisions in Pennsylvania and Kentucky. Enrollment decreased during the boom and increased in the subsequent bust. Similar evidence of exogenous increases in low skilled wages and employment are found by Evans and Kim (2006). They studied changes in education decisions after casinos opened on Native American reservations. Evans and Kim found that opening a casino increased employment and wages of low-skilled workers. Students responded by dropping out of high school more often and attending college less often. Additionally, Rees and Mocan (1997) found worse labor market conditions (higher school district unemployment rates) decreased high school dropout rates in New York State.

If bank branching deregulation caused a disproportionate change in labor markets then it could change educational attainment. Beck et al. (2010) suggested that deregulation raised the income 
and employment hours of low skilled individuals. This means low skill jobs have increased returns relative to high or medium skilled jobs. It follows that, on the margin, individuals would lower educational investment since low skilled jobs became relatively better paying and more available after deregulation.

Jerzmanowski and Nabar (2011) found opposing results. They suggested that, following the same deregulations, wages of skilled labor increased and wages of unskilled labor decreased. Thus, on the margin, educational attainment would increase as individuals try and earn those heightened wages at high skilled jobs. ${ }^{10}$

Additionally, over a long time horizon, increased economic growth due to bank deregulation could improve the home lives of children. One of the most important determinates of high school graduation is social and emotional development (Murnane, 2013). A better home life during formative years can improve this development and increase the chances that an individual graduates high school by increasing her cognitive or social/emotional abilities (Murnane, 2013; Caucutt and Lochner, 2012). Thus, in the long run, there could be some increase in high school graduation associated with deregulation via better home life.

Labor markets could also be affected disproportionately with respect to race or gender. Black and Strahan (2002) and Kerr and Nanda (2009) found that bank branching deregulation encouraged entrepreneurship, creative destruction, and competition. Greater competition rewards efficient, innovative companies while inefficient companies entrenched in their ways fail. This creative destruction may affect labor market discrimination (Becker, 1957). Less discrimination can improve labor market conditions for minorities and women laborers. This increases the benefits of education for females and minorities and may increase their educational outcomes

\footnotetext{
${ }^{10}$ Beck et al. and Jerzmanowski and Nabar seem to demonstrate opposite results. However, using the analysis of Bedard (2001) might erase the stark contrast of these two sets of results. Jerzmanowski and Nabar split individuals into categories of skilled and unskilled and place high school graduates that did not attend college in the unskilled bin. This does not match with the high/medium/low skilled, college/high school/dropout split in Bedard's (2001) analysis. If Bedard's signaling theory is correct, the relative change in ability of dropouts is increasing and ability of high school graduates who do not attend college are decreasing. Thus, even if wages of high skilled individuals are relatively higher, a la Jerzmanowski and Nabar, the gap of pay between high school degree earners and high school dropouts could decrease following the bank branching deregulation, reducing income inequality as suggested in Beck et al. (2010).
} 
relative to white men. Levine et al. (2014) found similar outcomes when looking at deregulation's effects on income of African Americans.

Because of these various and contradicting channels, the educational attainment response to bank branching deregulation is unpredictable. The results may find positive relationships between deregulation and college achievement as Levine and Rubinstein (2013) and Sun and Yannelis (2016) find greater college attendance associated with bank deregulation and increased attendance will likely increase achievement.

Results from Beck et al. (2010) and Bedard (2001) suggest low ability individuals may, on the margin, drop out of high school more frequently, although Jermanowski and Nabar (2011) suggest the opposite. Additionally, heterogeneous effects of timing of educational investment as highlighted in Caucutt and Lochner (2011) suggest more positive effects on educational attainment for individuals who were young children when the deregulation occurred. Increased competition suggested by Black and Strahan (2002) and Kerr and Nanda (2009) may indicate greater educational attainment for women and minorities due to increased opportunity cost created by improved labor market outcomes.

\section{Data and Methods:}

\section{III.1 Methods}

The typical approach in the literature identifies the year when bank deregulation occured in a state and employs a difference-in-differences approach based on this timing to explain observed variation in data aggregated to the state level. This study differs in several. First, I analyze individual level data, not statewide aggregate data. However, I do not follow individuals through time. Linear probability models (LPMs) are estimated because of the bivariate nature of the educational attainment variables. LPMs are also used in Sun and Yannelis (2016).

The linear probability model applies the OLS estimator to a binary dependent variable. The base regression model estimated is:

$$
Y_{i s t}=\alpha+\theta_{s}+\tau_{t}+\phi \text { Dereg }_{i s t}+\boldsymbol{X}_{i s t} \mathbf{B}+\boldsymbol{A} \boldsymbol{G} \boldsymbol{E}_{i s t} \boldsymbol{\Gamma}+\epsilon_{i, s, t},
$$

where $Y_{i s t}$ is an educational attainment indicator variable of interest. $\theta_{s}$ is a state specific indicator, $\tau_{t}$ is the year specific indicator. The variable of interest is Dereg $_{i s t}$ the bank branching 
deregulation variable. The bolded variables and coefficients are vectors. $\boldsymbol{X}_{i s t}$ contains the individual specific variables of central city (lives in city center), MSA (lives in a MSA but not in the central city), nonwhite (is $i$ nonwhite), and male (is $i$ male). $\boldsymbol{A} \boldsymbol{G} \boldsymbol{E}_{\boldsymbol{i}}$, is a vector of indicator variables for all but the youngest age included in the regression. ${ }^{11,12} \epsilon_{i, s, t}$ is the normally distributed random error term with mean zero for individual $i$.

To account for heterogeneous effects of deregulation on race and gender the sample is split into four subsamples: nonwhite females, nonwhite males, white females, and white males. ${ }^{13}$

Regression models for these subsamples are estimated separately using equation (1) with race and gender variables omitted.

Similar models are used to identify the difference in effects of deregulation on residents of unit banking states versus states with other levels of branching restrictions. I split the sample for individuals living in unit banking states and those not and estimate separate models.

The Probit estimator is used as a robustness check. Probit estimates whether or not the bivariate dependent variable, $Y_{i s t}$,equals 1 using a maximum likelihood approach. $\Phi(\quad)$ is the cumulative distribution function of the unit-normal distribution

$P\left(Y_{i}=1 \mid \theta_{s}, \tau_{t}\right.$, Dereg $\left._{i s t}, \boldsymbol{X}_{i s t}, \boldsymbol{A} \boldsymbol{G} \boldsymbol{E}_{i s t}\right)=\Phi\left(\alpha+\theta_{s}+\tau_{t}+\phi \operatorname{Dereg}_{i s t}+\boldsymbol{X}_{i s t} \mathbf{B}+\boldsymbol{A} \boldsymbol{G} \boldsymbol{E}_{i s t} \boldsymbol{\Gamma}+\epsilon_{i, s, t}\right)$

\section{III.2 Identifying the Treatment Group}

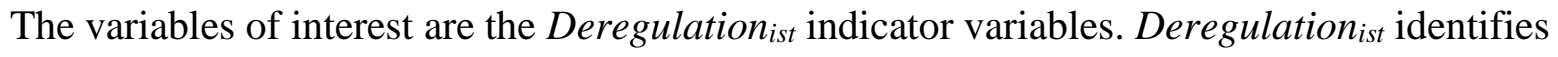
individuals whose educational attainment could plausibly have been influenced by mergers and acquisitions bank branching deregulation. Although the identification process has some limits, the data available can be used to identify a treatment group under certain assumptions.

This analysis focuses on how bank branching deregulation affected educational achievement. Individuals who have already reached some educational achievement (graduated high school,

\footnotetext{
11 The youngest age in the set (typically age 20), the state Maine, and the year 1977 do not have dummy variables to allow the use of a constant in the regressions.

${ }^{12}$ Older individuals are more likely to graduate high school. Also, there is probably some nonlinearity in age. Being 21 rather than 20 increases the likelihood of graduating high school more than being 29 rather than 28.

${ }^{13}$ In earlier drafts, interaction terms were used to highlight the differences in race and gender, however, this restricted the coefficients to a single value for each race and gender leading to biased estimates.
} 
earned an associate's degree, etc) by the time deregulation occurs should not be included in the treatment group. A new policy cannot affect an outcome already decided. For instance, in terms of high school graduation, if an individual graduates high school in 1980 but deregulation occurred in 1981 in her state of residence, then the deregulation cannot have had any effect on her decision to stay in school and graduate high school.

The March CPS does not identify the year each individual graduated high school. I instead use the fact that most individuals do not graduate high school before age 17 and use the data I have on individuals' ages to sort them into treated and control groups. If an individual was 17 or under at the time of deregulation, then they are identified as treated. I use this same identification when focused on post-secondary degree earners, because most decisions about college attendance are made around the same time as high school graduation. This will also provide some consistency across models.

Deregulation $_{\text {ist }}$ is an indicator variable identifying the treatment group: individuals exposed to deregulation before graduating high school. Its value relies on information about individual, $i$, specifically the state where $i$ currently lives, the year when $i$ was interviewed, and $i$ 's age when interviewed. Deregulation ist $=1$ if individual $i$ was under the age of 18 when the state individual $i$ lives in was deregulated. Otherwise, Deregulation $_{i s t}=0$.

Why are 17 year olds at the time of deregulation included and 18 year olds are not? Either way, this identification strategy introduces measurement error into regression models by including some treated individuals in the control group and some non-treated individuals in the treated group. In my sample, $78.3 \%$ of 19 year olds have graduated high school, $45.5 \%$ of 18 year olds have graduated high school, and $5.4 \%$ of 17 year olds have graduated high school. ${ }^{14,15}$ Thus, I will not include individuals aged 18 or higher in the treatment group.

Because I do not want to include individuals that, at the time of deregulation, had yet to finish high school in the control group, I exclude individuals whose age at the time of deregulation was 18 or 19 from all estimations. Measurement error from graduation age is mostly random, created

\footnotetext{
14 These are percentages of the entire sample population, not just those who will one day graduate high school. 15 The effect of excluding 17 year olds from the treatment group is addressed in robustness checks. Only $0.6 \%$ of 16 year olds graduated high school in this sample.
} 
by differences in day and month of birth. However, most of this random error is eliminated by excluding observations of those individuals aged 18 and 19 in the year of deregulation.

There may be some systematic error left over. It is likely that only low ability individuals would be improperly placed in the control group, 20 year olds or older still in high school. It is also likely that only high ability individuals would be improperly placed in the treated group because they graduated before age 17. This could bias the deregulation coefficient upward. However, this applies to such a small portion of the sample that the bias is likely unimportant.

The following three examples illustrate the construction of the treatment group. ${ }^{16}$

1. Ian is surveyed in 1990, when, he is 34 years old and lives in Pennsylvania. Ian was born in 1954. From table 1, Pennsylvania deregulated bank branching in 1982, when Ian was 28 years old. He was too old for the deregulation to have affected his high school attainment decision, thus, Deregulation $n_{\mathrm{IAN}}=0$.

2. Jenn is surveyed in 1987 when she is 30 years old and living in Maine. Maine deregulated banks in 1975 when Jenn was 18. She was older than 17 when the bank branching deregulation occurred, thus, Deregulation $\mathrm{JENN}=0$. However, because she was only 18 when the deregulation occurred, it is probable that Jenn was treated if she was still in high school at age 18. So I exclude Jenn from the sample.

3. Kate is surveyed in 1980. At that time, she is 21 and lives in New York State. New York deregulated in 1976. Kate was 17 in 1976, so, Deregulation KATE $=1$.

A problem with this identification strategy is that some individuals moved to another state after high school and thus were not influenced by deregulation in their current state of residence. This unobserved migration across state lines introduces measurement error. This movement may be tied to educational attainment. Higher educated individuals are likely more able to move and to move than lower educated individuals. Higher educated individuals more likely have experience

\footnotetext{
16 To create Deregulation $_{i s t}$ I use information from the CPS on the age, $A G E_{i}$, of each individual, $i$, the year, $Y E A R_{i}$, and the state of residence, $s_{i}$. I create a variable called Deregulation_year ${ }_{i}$, which takes the value of the year of bank branching deregulation of state, $s_{i}$. I then create another variable called age_at_deregulation $n_{i}$, which takes the value of individual $i$ 's age in the year when state, $s_{i}$, was deregulated: age_at_deregulation $n_{i}=\left(\right.$ deregulation_year $_{i}-$ $\left.\left(Y E A R_{i}-A G E_{i}\right)\right)$. Then I create the bank branching deregulation treatment variable, Deregulation $_{i, s, t}$, which takes a value of 1 when age_at_deregulation ${ }_{i}<18,0$ otherwise, unless differently specified.
} 
away from home, e.g. going to college out of state. Also, higher educated individuals usually have greater means to move, both financial and time to search.

However, most migration decisions are likely uncorrelated with deregulation. People are unlikely to move to another state to gain access to banks with less branching regulation. ${ }^{17}$ Migration from state to state is independent of deregulation. So, noise created by interstate migration should act to bias deregulation estimates toward zero. Nonetheless, to avoid some measurement error, I restrict the sample to individuals under 30 in most models. These individuals have less opportunity to move.

There may be differences in the effects of deregulation on education given individuals' age at deregulation. Research has shown increased effects of relaxing credit constraints on younger children (Caucutt and Lochner, 2012). To check this effect I generate the variable: Age at deregulation: 12 and under $_{\text {ist }}$, which identifies individuals 12 and under at the time of deregulation. Because the education of individuals aged 13 through 17 at time of deregulation are plausibly affected by deregulation I excluded them from the sample (as I do with those aged 18 or 19 at the time of deregulation in all models) when estimating Age at deregulation: 12 and under ist

\section{III.3 Control Variables}

This study uses data from the CPS March Supplement 1977 to 1999. The March supplement contains a rich store of micro data. Data from years prior to 1977 do not identify the exact state an individual lives in. Nonetheless, this data provides a timeframe where most of the variation in state bank branching deregulation occurred; 36 states deregulated in those years.

The last intrastate deregulation occurred in 1999: all other states deregulated by 1994. Ending in 1999 allows a few years to glean information from treated individuals in states like Arkansas and Minnesota. Limiting the dates from 1977 to 1999 narrows the set to 3.5 million observations. I

\footnotetext{
${ }^{17}$ However, bank branching deregulation is found to increase economic growth, so there may be some systematic movement toward deregulated states, especially by more educated individuals who have greater means to migrate. Estimations excluding individuals moving in the past year are included in the robustness section to investigate the effect of measurement error.
} 
exclude states deregulating before 1970 as it is difficult to find branching deregulation dates. ${ }^{18}$ This decreases the number of observations to about 2.7 million.

Individuals aged below 20 are omitted as there are many reasons why they might not have completed high school. ${ }^{19}$ Those aged 30 and above are dropped to limit the effects of migration out of their home state. Also, to avoid measurement error, I excluded individuals aged 18 or 19 at the time the state they live in deregulated. This leaves about 387,000 observations in the base model.

It is important to control for other factors affecting educational attainment to limit omitted variable bias. Murnane (2013) describes many indicators lowering the opportunity cost of learning or moving up a grade level. Herein lies one limitation of this study. The CPS contains no data on individuals during adolescence. It does not indicate family wealth, enrollment in prekindergarten, parent education levels, etc.

The models include demographic, geographic, age, and year control variables. I include an

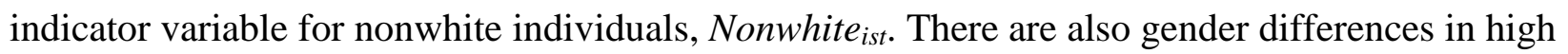
school graduation rates. These are captured by the indicator variable, Male ist. $_{\text {. Also included are }}$ geographic indicator variables Central City ist and $M S A_{i s t}{ }^{20}$ Central city $_{i s t}$ indicates that the individual lives in a central city. $M S A_{\text {ist }}$ indicates that individual $i$ lives in a metropolitan area but

\footnotetext{
${ }^{18}$ Rhode Island, South Dakota, Delaware, Maryland, D.C., North Carolina, South Carolina, Idaho, Nevada, Arizona, California, and Alaska deregulated bank branching before 1970. Levine and Rubinstein (2013) suggest that these states all deregulated in 1960, but the source they cite, Kroszner and Strahan (1999), only indicates that these states deregulated prior to 1970 . For most studies of bank branching deregulation this does not matter greatly because they are interested in how branching deregulation effects the macroeconomy. In this paper, however, the setup of the treatment group relies heavily on the exact year that these states deregulated. For instance, Dale is a 29 year old living in Delaware in 1977. If Delaware deregulated in 1969, Dale should be placed in the control group. If Delaware deregulated in 1960 then Dale should be marked as treated. Using bank branching deregulation dates from Levine and Rubinstein, all states are included in a robustness estimation, but most regression omit these 11 states and D.C.

${ }^{19}$ This will eliminate most interference from students being held back a grade or even changes to state laws restricting entry into kindergarten.

${ }^{20}$ CentralCity and MSA seem less important than Nonwhite and Female in determining education because these only indicate whether the individual is living in a city or MSA at the time of the survey, whereas individuals who are nonwhite or female at the time of the survey were that way their whole lives. If there is some persistence to type of area on individual lives (city, MSA, or rural) then we might be able to tie where an individual lives to the probability they graduated high school. However, individuals with low skills (high school dropouts) likely flock to cities as a place with greater opportunity and also greater public good production such as transportation (Glaeser et al. 2006). Additionally, cities have lower high school graduation rates. Not graduating high school makes it harder to find a job and harder to move, so there may be lower levels of graduates in cities for that reason.
} 
outside of the central city, i.e. the suburbs. Individuals living in rural areas or individuals not answering which type of area they live in take the value of 0 for both of these indicators.

There are several educational outcome variables of interest. High School Graduate ist $_{\text {takes }}$ the value of 1 if individual $i$ has received a high school degree or equivalent, 0 otherwise. ${ }^{21}$ College $_{\text {ist }}$ takes the value of 1 if individual $i$ has attended college, 0 otherwise. For data gather in

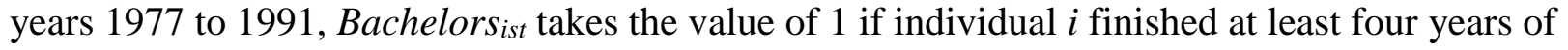

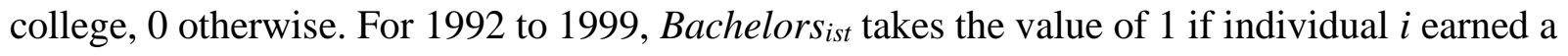
Bachelor's Degree or higher, 0 otherwise.

Table 2 presents summary statistics of the described variables. All averages except age represent the proportion of the sample population with that attribute.

\section{Results}

Bank branching deregulation, in the form of within state mergers and acquisitions, is associated with an increased likelihood of graduation from high school. Table 3, shows four model specifications. The first is without state or year dummies, next with state dummies and without year dummies, third with year dummies and without state dummies, and the last with both year and state dummies.

The models with indicators for state, year, and age suggests individuals living in the suburbs are more likely to have graduated high school than individuals living in rural areas. Females are more likely to graduate high school. Nonwhite individuals have lower probability of graduating high school than whites. The coefficient of interest suggests individuals identified by the deregulation indicator are 1.0 percentage point more likely to graduate high school.

However, this increase is only present for white individuals. Table 3 splits the data into four subsamples: white males, white females, nonwhite males, and nonwhite females. White males are 1.3 percentage points more likely to graduate high school after the deregulation. White females are 1.0 percentage points more likely. There are no significant effects for nonwhite males or nonwhite females.

\footnotetext{
${ }^{21}$ The CPS includes GED recipients which may distort economic impact of increased high school graduation in this study, see Cameron and Heckman (1993).
} 
The change in the likelihood of graduating high school for white males and white females after deregulation indicates deregulation affects educational achievement through a labor market channel, as credit markets for students and their families should not affect high school attendance and graduation. The positive sign suggests higher skilled jobs are more positively affected than low skilled jobs by bank branching deregulation. More specifically, jobs available to high school graduates are more positively affected by deregulation than jobs available to individuals with no high school degree.

The positive relationship between high school graduation and deregulation does not necessarily indicate a labor market channel. For instance, if access to more credit nudged marginal individuals to graduate high school or earn GEDs as a stepping stone to receiving a more affordable college degree, then increased high school graduation due to deregulation does not sufficiently prove existence of labor market channel. Table 4 shows the estimates when modeling high school graduation including only individuals who have not attended college. Although there are no significant effects, the point estimates of deregulation's effect on high school graduation are similar to those in the full sample. These results do not provide evidence indicating that deregulation influenced individuals to, on the margin, graduate high school due to the lure of more affordable college.

Table 5 presents the effects of bank branching deregulation on higher education outcomes. The first two specifications analyze college attendance of white males and white females respectively. White males see no significant change in college attendance after deregulation. However, the point estimate is close to that of white females who increase college attendance 2.2 percentage points after deregulation. ${ }^{22}$

The last two specifications in Table 5 analyze bachelor degree achievement of white males and white females respectively. White males see a 2.1 percentage point increase in bachelor's degree attainment. White females enjoy a similar increase in likelihood of earning a bachelor's degree.

The greater effects of banking deregulation on college attendance and bachelor's degree achievement is expected. Both labor market and credit market channels are active for college

\footnotetext{
${ }^{22}$ Sun and Yannelis (2016) find similar increases in college attendance of 2.6 percentage points. Due to the limitation of the identification strategy utilized here, the estimates here are lower bounds. So, 2.6 percentage points could represent the true change.
} 
attendance and achievement. Naturally, the additional channel boosts the effectiveness of deregulation. Also, the credit channel is more of a direct effect of the cost savings for banks. The indirect labor market channel is not likely to be as effective since economic growth is spread amongst both labor and physical capital markets.

Table 6 presents results splitting observations into two subsets: states with a history of unit banking and states with all other types of geographic restrictions leading up to merger and acquisition bank branching deregulation. Deregulating directly from unit banking rather than from some less restrictive policy is a more radical change to intrastate branching and may generate a greater overall effect on educational outcomes. The first two specifications represent models of high school graduation for unit banking states and non-unit banking states respectively. Neither of these models identify deregulation as a significant factor in explaining high school graduation. ${ }^{23}$

The last two specifications in Table 6 analyze bachelor's degree attainment in unit banking and non-unit banking states respectively. Individuals living in non-unit banking states increase their likelihood of bachelor's degree attainment by 2.6 percentage points. Bachelor degree attainment by residents of unit banking states were unaffected by deregulation policy.

This is a puzzling result. The timing of deregulation in unit banking states is generally later than the timing in non-unit banking states. ${ }^{24}$ Unit banking states are also clustered toward the middle of the country. These systematic differences may bias the estimates. Additionally, before 1992, bachelor's degree $_{i s t}=1$ indicates that individual, $i$, completed at least 4 years of college. Whereas, for 1992 onward, bachelor's degree $e_{i s t}=1$ signifies that individual, $i$, earned a bachelor's degree. In the unit-banking model, this difference in the dependent variable puts emphasis on deregulation's effect on degree attainment due to the later timing of deregulation in unit-banking states.

Previous research suggests policy impacts are greater for younger individuals (Carneiro and Heckman, 2002; Caucutt and Lochner, 2011). Table 8 presents a test of this claim. Models with

\footnotetext{
${ }^{23}$ The unit banking model has a p-value of about .051 and when using a probit model deregulation is significant at the 0.05 alpha level.

${ }^{24} 14$ out of 15 unit banking states deregulated after 1986. 17 of 24 non-unit banking states deregulated before 1987. See table 1 .
} 
only younger individuals (those aged 12 and under) at the time of deregulation included in the treatment group have higher estimated probability than of individuals 17 and under (1.4 as opposed to 1.0). However, the coefficient estimates are not significantly different from one another, so this does not provide strong evidence for or against the idea that deregulation affected younger individuals.

Results in the column labeled "Attended College" in Table 7 suggests that younger individuals, although more likely to graduate high school, are not significantly more likely to attend college. Yet according to the last specification, they are significantly more likely to earn a bachelor's degree. This may be evidence that the increase in college attendance is short lived and mainly affected those individuals who were in high school when deregulations occurred. The increase in achievement in both high school and college may suggest increased ability. It could also indicate economic growth due to bank branching deregulation took years to percolate through to labor market expectations.

Another explanation for increases in the likelihood of earning both high school and bachelor's degrees could be an increase in competition in business. Bank deregulation leads to easier credit increasing entrepreneurship and creative destruction (Black and Strahan, 2002; Kerr and Nanda, 2009). This increases competition in many industries. Employers may become more wary on the hiring side, stipulating stricter degree requirements to qualify employees for jobs. So, even though college attendance is not increasing, individuals entering college have incentive to seek higher degrees, bachelor's instead of associate's for instance.

\section{Robustness}

Table 8 summarizes robustness checks where high school graduation is the dependent variable. In Table 8, specification 1 is the original results for comparison. Specification 2 uses a probit model rather than a linear probability model, as the OLS LPM estimation technique assumes normal and homoskedastic errors, which may not hold here. The point estimates are nearly identical and the errors are actually larger for the LPM specification than the probit, which suggests the LPM method with errors clustered by state provides satisfactory results.

Specification 3 changes the treatment group by restricting the treatment age at the year of deregulation to be 16 and under rather than 17 and under, eliminating some possibly systematic 
measurement error. Some individuals may have graduated high school at age 16 or before the deregulation occurred when they were 17. This specification omits those individuals from the sample. The results are no different from the baseline specification.

Specifications 4 and 5 check robustness by varying the sample years. Specification 4 and 5 start the sample in 1977, but end the sample years at 1994 and 1989 respectively. The point estimates are no different when sample years are changed. This indicates that the selection of sample years of 1977 to 1999 is not biasing the results.

One of the assumptions made when identifying the treatment was that migration from state to state is independent of deregulation, and, therefore, estimates of deregulation's effect on education are lower bounds. To test this claim, specification 6 amends the original model by restricting the sample to exclude individuals who indicated they moved to their current state of residence in the past year. ${ }^{25}$ The point estimates and significance levels are unchanged so there is no evidence of systematic measurement error due to interstate migration in the last year.

Specification 7 includes observations from all states, including the 11 states and D.C. that deregulated prior to 1970 . The deregulation dates used for those states and D.C. are from Levine and Rubinstein (2014). This does not change sign or significance. This will mainly add observations to the treatment group because, according to Levine and Rubinstein, the 11 states and D.C. deregulated in $1960 .^{26}$

Table 9 presents results of estimations using false deregulation dates. Each state's false deregulation date is randomized so the distribution of false dates matches the distribution of true dates. The randomization strategy is as follows. Each state is given a random number from a uniform distribution from 0 to 1 . The smallest random number is matched with the earliest deregulation date. The second smallest random number is matched with the next earliest deregulation date, etc.

\footnotetext{
25 This could perhaps stop individuals from moving back to the state they lived in when they were younger. However, this likely lowers the overall measurement error.

${ }^{26}$ I am uncertain of when these states deregulated. I find no evidence to support Levine and Rubinstein's deregulation dates. Most papers relying on Krozner and Strahan (1999) report only that these 11 states and D.C. deregulated prior to 1970 .
} 
Holding constant the distribution of bank branching deregulation timing but randomizing the state that deregulated using that timing distribution can help asses if the results are spurious. If the effect of deregulation is the same when the dates are randomized, then the results may be spurious. After randomization of deregulation timing, deregulation has no effect on the likelihood of high school graduation. Therefore, there is no evidence of a spurious relationship.

\section{Conclusion}

Bank branching deregulation increased educational attainment. It is difficult to identify the channels responsible for these effects. However, high school graduation increasing due to deregulation suggests a labor market channel exists. Most high schools do not charge tuition and therefore credit channels are not likely to affect high school graduation. Larger effects on college attainment is evidence of a credit channel whereby deregulation affects post-secondary attendance and achievement.

I find no differences in deregulation affecting educational achievement by gender. Race, however, proved an important factor. White individuals as a group were significantly affected while non-white individuals, on average, saw no change to their educational attainment after deregulation. This result is not surprising. Cameron and Heckman (2001) suggested that nonwhite individuals react less to policies regarding labor or credit markets because the underlying detriment to education developed by these groups in early childhood. Changes to affordability or benefits of education that are not noticed until middle school cannot have a strong effect because the individual has already lost potential in ability and/or developed personality conflicting with traditional academics.

This research extends Levine and Rubinstein (2013) and Sun and Yannelis (2016) by looking at effects of deregulation not only on college enrollment, but on high school graduation as well. By focusing on high school graduation, this research provides additional evidence supporting a labor market channel suggesting that bank branching deregulation increased labor market conditions for high school degree earners relative to drop outs. The similar estimates for increases in college attendance and bachelor's degree achievement also strengthens evidence found in previous papers. 
There are data limitations in this study. Future research should focus on effects of banking deregulation on high school graduation using longitudinal data. The ability to track individuals through time will improve identification of the treatment group and can help correct for the influence of omitted variables such as family income and parental educational background. The ability to track lifetime individual residence could take better advantage of variation in the timing of bank branching deregulation.

\section{References:}

Beck, T.; R. Levine, and A. Levkov. "Big Bad Banks? The Winners and Losers from Bank Deregulation in the United States." The Journal of Finance, 65, 2010, 1637-67.

Becker, G. "The Economics of Discrimination.” University of Chicago Press, Chicago. 1957.

Bedard, K. "Human Capital Versus Signaling Models: University Access and High School Dropouts.” Journal of Political Economy, 109, 2001, 749-75.

Benmelech, E., N.K. Bergman, and A. Seru. "Financing Labor." NBER Working Paper 17144, 2011.

Black, D. A., T. G. McKinnish, and S. G. Sanders. "Tight Labor Markets and the Demand for Education: Evidence from the Coal Boom and Bust." Industrial and Labor Relations Review, 59, 2005, 3-16

Black, S. E. and P. E. Strahan. "Entrepreneurship and Bank Credit Availability." The Journal of Finance, 57, 2002, 2807-33.

Bridgeland, J. M., J. J. Dilulio Jr., K. B. Morison. "The Silent Epidemic: Perspectives of High School Dropouts." Civic Enterprises, 2006.

Boustanifar, H. "Finance and Employment: Evidence from U.S. Banking Reforms." Journal of Banking and Finance, 46, 2014, 343-54.

Cameron, S. V. and J. J. Heckman. "The Nonequivalence of High School Equivalence." Journal of Labor Economics 11, 1993, 1-47.

Cameron, S. V. and J. J. Heckman. "The Dynamics of Educational Attainment for Black, Hispanic, and White Males." Journal of Political Economy 109, 2001, 455-99.

Carneiro, P. and J. J. Heckman. "The Evidence on Credit Constraints in Post-Secondary Schooling." The Economic Journal, 112, 2002, 705-34.

Caucutt, E. M. and L. Lochner. "Early and Late Human Capital Investments, Borrowing Constraints, and the Family." NBER Working Paper No. 18493, 2012.

Clarke M. Z. "Geographic Deregulation of Banking and Economic Growth.” Journal of Money, Credit, and Banking, 36, 2004, 929-42. 
Evans, W. N. and W. Kim. "The Impact of Local Labor Market Conditions on the Demand for Education: Evidence from Indian Casinos.” U.S. Census Bureau Center for Economic Studies, 2006.

Glaeser, E. L., M. E. Kahn, and J. Rappaport. "Why Do the Poor Live in Cities? The Role of Public Transportation.” Journal of Urban Economics, 63, 2008, 1-24.

Jayaratne, J. and P. E. Strahan. "The Finance-Growth Nexus: Evidence from Bank Branch Deregulation.” The Quarterly Journal of Economics, 111, 1996, 639-70.

Jerzmanowski, M. and M. Nabar. "Financial Development and Wage Inequality: Theory and Evidence.” Economic Inquiry, 51, 2013, 211-34.

Kerr, W. R. and R. Nanda. "Democratizing Entry: Banking Deregulation, Financing Constraints, and Entrepreneurship.” Journal of Financial Economics, 94, 2009, 124-49.

Kroszner, R. S. and P. E. Strahan. "What Drives Deregulation? Economics and Politics of the Relaxation of Bank Branching Restrictions." Quarterly Journal of Economics, 114, 1999, 1437-67

Kroszner, R. S. and P. E. Strahan. "Regulation and Deregulation of the U.S. Banking Industry: Causes, Consequences, and Implications for the Future." University of Chicago Press, NBER. Book chapter: Economic Regulation and Its Reform: What Have We Learned? Ed. Rose, Nancy L., 2014, 485-543.

Krueger, A. O. "The Political Economy of the Rent-Seeking Society." The American Economic Review, 64, 1974, 291-303.

Levine, R., A. Levkov, and Y. Rubinstein. "Bank Deregulation and Racial Inequality in America." Critical Finance Review. 3, 2014, 1 - 48.

Levine, R. and Y. Rubinstein. "Liberty for More: Finance and Educational Opportunities." NBER Working Paper No. 19380, 2013.

Lochner, L. and A. Monge-Naranjo. "Credit Constraints in Education." NBER Working Paper number 17435, 2011.

McChesney, F. S. "Rent Extraction and Rent Creation in the Economic Theory of Regulation." The Journal of Legal Studies. 16.1, 1987, 101-118

Murnane, R. J. “U.S. High School Graduation Rates: Patterns and Explanations.” Journal of Economic Literature, 51, 2013, 370-422.

Oreopoulos, P. "Do Dropouts Drop Out too soon? Wealth, health and Happiness from Compulsory Schooling.” Journal of Public Economics, 91, 2007, 2213-29.

Stiroh K. J. and P. E. Strahan. "Competitive Dynamics of Deregulation: Evidence from U.S. Banking." Journal of Money, Credit, and Banking, 35, 2003, 801-28. 
Rees, D. I. and H. N. Mocan. "Labor Market Conditions and the High School Dropout Rate: Evidence from New York State.” Economics of Education Review, 16, 1997, 103-09.

Rumberger, R. W. "High School Dropouts: A Review of Issues and Evidence.” Review of Educational Research, 57, 1987, 101-21.

Sun, S. T. and C. Yannelis. "Credit Constraints and Demand for Higher Education: Evidence from Financial Deregulation.” Review of Economics and Statistics, 98, 2016, 12-24.

Sylla, R., J. B. Legler, and J. J. Wallis. "Banks and State Public Finance in the Republic: The United States, 1790-1860.” Journal of Economic History 47, 1987, 391-403.

Tullock, G. "The Welfare costs of Tariffs, Monopolies, and Theft.” Economic Inquiry, 5, 1967, 224-32.

White, L. J. The S\&L Debacle: Public Policy Lessons for Bank and Thrift Regulation. New York: Oxford University Press. 1991. 
Table 1: Intrastate Branch Deregulation Via Merger and Acquisitions, by Year

\begin{tabular}{|c|c|c|c|}
\hline State & Year & State & Year \\
\hline Alaska & $<1970$ & Tennessee & 1985 \\
\hline Arizona & $<1970$ & Washington & 1985 \\
\hline California & $<1970$ & Hawaii & 1986 \\
\hline Delaware & $<1970$ & Mississippi & 1986 \\
\hline District of Colombia & $<1970$ & Kansas* & 1987 \\
\hline Idaho & $<1970$ & Michigan & 1987 \\
\hline Maryland & $<1970$ & New Hampshire & 1987 \\
\hline Nevada & $<1970$ & North Dakota* & 1987 \\
\hline North Carolina & $<1970$ & West Virginia* & 1987 \\
\hline Rhode Island & $<1970$ & Florida* & 1988 \\
\hline South Carolina & $<1970$ & Illinois * & 1988 \\
\hline South Dakota & $<1970$ & Louisiana & 1988 \\
\hline Vermont & 1970 & Oklahoma* & 1988 \\
\hline Maine & 1975 & Texas* & 1988 \\
\hline New York & 1976 & Wyoming & 1988 \\
\hline New Jersey & 1977 & Indiana & 1989 \\
\hline Virginia & 1978 & Kentucky & 1990 \\
\hline Ohio & 1979 & Missouri* & 1990 \\
\hline Connecticut & 1980 & Montana* & 1990 \\
\hline Alabama & 1981 & Wisconsin* & 1990 \\
\hline Utah & 1981 & Colorado* & 1991 \\
\hline Pennsylvania & 1982 & New Mexico & 1991 \\
\hline Georgia & 1983 & Minnesota* & 1993 \\
\hline Massachusetts & 1984 & Arkansas* & 1994 \\
\hline Nebraska* & 1985 & Iowa* & 1999 \\
\hline Oregon & 1985 & & \\
\hline
\end{tabular}


Table 2: Summary Statistics

\begin{tabular}{|c|c|c|c|}
\hline & Obs. & Mean & Standard Deviation \\
\hline High School Graduate & 386,841 & 0.859 & 0.348 \\
\hline Attend College & 386,841 & 0.484 & 0.500 \\
\hline Associate's Degree & 386,841 & 0.376 & 0.484 \\
\hline Bachelor's Degree & 386,841 & 0.167 & 0.373 \\
\hline Master's Degree (+) & 386,841 & 0.023 & 0.149 \\
\hline Central City & 386,841 & 0.257 & 0.437 \\
\hline MSA not Central City & 386,841 & 0.316 & 0.465 \\
\hline Male & 386,841 & 0.482 & 0.500 \\
\hline Nonwhite & 386,841 & 0.134 & 0.341 \\
\hline Age & 386,841 & 24.60 & 2.87 \\
\hline Deregulation & 386,841 & 0.315 & 0.465 \\
\hline \multicolumn{4}{|c|}{$\begin{array}{l}\text { Notes: Data in the statistical summary are from the CPS March supplement: years } 1977 \text { to } 1999 \text {, ages } 20 \text { to } 29 \text {. } \\
\text { Sample weights provided by the CPS were used. High School Graduate takes a value of } 1 \text { if an individual has } \\
\text { graduated high school or earned an equivalent degree, } 0 \text { otherwise. Likewise for the other education attainment } \\
\text { variables. Central City indicates whether an individual lives in a central city, taking an affirmative value of } 1,0 \\
\text { otherwise. MSA indicates that an individual's residence is located within a metropolitan statistical area with a } \\
\text { value of } 1,0 \text { otherwise. Male indicates that an individual is female with a value of } 1,0 \text { if male. Nonwhite } \\
\text { indicates an individual considers him or herself nonwhite with a value of } 1,0 \text { otherwise. Age indicates the age of } \\
\text { the individual surveyed. Deregulation takes the value of } 1 \text { if the individual was under } 18 \text { years old when the } \\
\text { state they live in deregulated bank branching via mergers and acquisitions, } 0 \text { otherwise. }\end{array}$} \\
\hline
\end{tabular}


Table 3: High School Graduation, by Race and Gender

\begin{tabular}{|c|c|c|c|c|c|}
\hline & \multicolumn{5}{|c|}{ High school graduate $($ Yes $=1$, No $=0)$} \\
\hline & 1 & 2 & 3 & 4 & 5 \\
\hline Central City & $\begin{array}{l}-0.010 \\
(0.015)\end{array}$ & $\begin{array}{l}-0.008 \\
(0.015)\end{array}$ & $\begin{array}{l}-0.019 \\
(0.016)\end{array}$ & $\begin{array}{c}0.022 \\
(0.021)\end{array}$ & $\begin{array}{c}0.015 \\
(0.020)\end{array}$ \\
\hline$M S A$ & $\begin{array}{c}0.052 * * * \\
(0.006)\end{array}$ & $\begin{array}{c}0.047 * * * \\
(0.006)\end{array}$ & $\begin{array}{c}0.049 * * * \\
(0.006)\end{array}$ & $\begin{array}{c}0.087 * * * \\
(0.019)\end{array}$ & $\begin{array}{c}0.086^{* * * *} \\
(0.018)\end{array}$ \\
\hline Male & $\begin{array}{c}-0.009 * * * \\
(0.002)\end{array}$ & & & & \\
\hline Nonwhite & $\begin{array}{c}-0.045^{* * *} * \\
(0.011)\end{array}$ & & & & \\
\hline Deregulation & $\begin{array}{c}0.010 * * \\
(0.004)\end{array}$ & $\begin{array}{c}0.013 * * * \\
(0.005)\end{array}$ & $\begin{array}{c}0.0010^{* *} \\
(0.004)\end{array}$ & $\begin{array}{l}-0.002 \\
(0.015)\end{array}$ & $\begin{array}{l}-0.006 \\
(0.013)\end{array}$ \\
\hline Constant & $\begin{array}{c}0.855 * * * \\
(0.005)\end{array}$ & $\begin{array}{c}0.845 * * * \\
(0.007)\end{array}$ & $\begin{array}{c}0.872 * * * \\
(0.006)\end{array}$ & $\begin{array}{c}0.819 * * * \\
(0.025)\end{array}$ & $\begin{array}{c}0.666 * * * \\
(0.020)\end{array}$ \\
\hline State Dummies & $\mathrm{X}$ & $\mathrm{X}$ & $\mathrm{X}$ & $\mathrm{X}$ & $\mathrm{X}$ \\
\hline Year Dummies & $\mathrm{X}$ & $\mathrm{X}$ & $X$ & $X$ & $\mathrm{X}$ \\
\hline Age Dummies & $\mathrm{X}$ & $\mathrm{X}$ & $\mathrm{X}$ & $\mathrm{X}$ & $X$ \\
\hline Female or Male & & Male & Female & Male & Female \\
\hline Nonwhite or White & & White & White & Nonwhite & Nonwhite \\
\hline Ages Observed & 20 to 29 & 20 to 29 & 20 to 29 & 20 to 29 & 20 to 29 \\
\hline Observations & 386841 & 163458 & 171538 & 22883 & 28962 \\
\hline
\end{tabular}


Table 4: High School Graduation, No College

\begin{tabular}{|c|c|c|c|}
\hline & \multicolumn{3}{|c|}{ High school graduate $($ Yes $=1$, No $=0)$} \\
\hline & 1 & 2 & 3 \\
\hline Central City & $\begin{array}{c}-0.063 * * * \\
(0.020)\end{array}$ & $\begin{array}{c}-0.076^{* * *} * \\
(0.024)\end{array}$ & $\begin{array}{c}-0.072 * * * \\
(0.022)\end{array}$ \\
\hline$M S A$ & $\begin{array}{c}0.048 * * * \\
(0.008)\end{array}$ & $\begin{array}{c}0.051^{* * * *} \\
(0.008)\end{array}$ & $\begin{array}{c}0.035^{* * * *} \\
(0.009)\end{array}$ \\
\hline Male & $\begin{array}{c}-0.018 * * * \\
(0.003)\end{array}$ & & \\
\hline Nonwhite & $\begin{array}{c}-0.039 * * \\
(0.017)\end{array}$ & & \\
\hline Deregulation & $\begin{array}{c}0.07 \\
(0.007)\end{array}$ & $\begin{array}{c}0.007 \\
(0.007)\end{array}$ & $\begin{array}{c}0.013 \\
(0.008)\end{array}$ \\
\hline Constant & $\begin{array}{c}0.765^{* * *} * \\
(0.008)\end{array}$ & $\begin{array}{c}0.798 * * * \\
(0.010)\end{array}$ & $\begin{array}{c}0.739 * * * \\
(0.012)\end{array}$ \\
\hline State Dummies & $\mathrm{X}$ & $\mathrm{X}$ & $\mathrm{X}$ \\
\hline Year Dummies & $\mathrm{X}$ & $\mathrm{X}$ & $\mathrm{X}$ \\
\hline Age Dummies & $\mathrm{X}$ & $X$ & $X$ \\
\hline Female or Male & Both & Female & Male \\
\hline Nonwhite or White & Both & White & White \\
\hline Attended College & No & No & No \\
\hline Ages Observed & 20 to 29 & 20 to 29 & 20 to 29 \\
\hline Observations & 199685 & 87018 & 83074 \\
\hline
\end{tabular}




\begin{tabular}{|c|c|c|c|c|}
\hline & $\begin{array}{l}\text { Attended } \\
\text { College }\end{array}$ & $\begin{array}{l}\text { Attended } \\
\text { College }\end{array}$ & $\begin{array}{c}\text { Bachelor's } \\
\text { Degree }\end{array}$ & $\begin{array}{c}\text { Bachelor's } \\
\text { Degree }\end{array}$ \\
\hline Central City & $\begin{array}{c}0.095 * * * \\
(0.017)\end{array}$ & $\begin{array}{c}0.075 * * * \\
(0.017)\end{array}$ & $\begin{array}{c}0.104 * * * \\
(0.012)\end{array}$ & $\begin{array}{c}0.095 * * * \\
(0.012)\end{array}$ \\
\hline$M S A$ & $\begin{array}{c}0.114 * * * \\
(0.012)\end{array}$ & $\begin{array}{c}0.102 * * * \\
(0.011)\end{array}$ & $\begin{array}{c}0.091 * * * \\
(0.009)\end{array}$ & $\begin{array}{c}0.076^{* * * *} \\
(0.009)\end{array}$ \\
\hline Deregulation & $\begin{array}{c}0.020 \\
(0.010)\end{array}$ & $\begin{array}{c}0.022 * * \\
(0.009)\end{array}$ & $\begin{array}{c}0.021 * * \\
(0.009)\end{array}$ & $\begin{array}{c}0.020 * * \\
(0.010)\end{array}$ \\
\hline Constant & $\begin{array}{c}0.397 * * * \\
(0.010)\end{array}$ & $\begin{array}{c}0.380 * * * \\
(0.008)\end{array}$ & $\begin{array}{c}0.151 * * * \\
(0.010)\end{array}$ & $\begin{array}{c}0.137 * * * \\
(0.009)\end{array}$ \\
\hline State Dummies & $\mathrm{X}$ & $X$ & $X$ & $\mathrm{X}$ \\
\hline Year Dummies & $X$ & $X$ & $X$ & $X$ \\
\hline Age Dummies & $\mathrm{X}$ & $\mathrm{X}$ & $\mathrm{X}$ & $X$ \\
\hline Female or Male & Male & Female & Male & Female \\
\hline Nonwhite or White & White & White & White & White \\
\hline Ages Observed & 20 to 29 & 20 to 29 & 24 to 29 & 24 to 29 \\
\hline Observations & 163458 & 171538 & 101177 & 105705 \\
\hline $\begin{array}{l}\text { Notes: Standard errors } \\
\text { table, the dependent var } \\
\text { education level, } 0 \text { other } \\
\text { mergers and acquisition }\end{array}$ & $\begin{array}{l}\text { is. **, and * } \\
\text { The depen } \\
\text { CPS March }\end{array}$ & $\begin{array}{l}\text { nt } 5 \text { and } 1 \mathrm{p} \\
\text { ble takes th } \\
\text { it data inclu }\end{array}$ & $\begin{array}{l}\text { Snificance le } \\
1 \text { if the ind } \\
\text { s } 1977 \text { to } 19\end{array}$ & $\begin{array}{l}\text { pectively. In thi } \\
\text { ttained that } \\
39 \text { states with }\end{array}$ \\
\hline
\end{tabular}


Table 6: Separated Samples by Unit Banking States

\begin{tabular}{|c|c|c|c|c|}
\hline & $\begin{array}{l}\text { High School } \\
\text { Graduate }\end{array}$ & $\begin{array}{l}\text { High School } \\
\text { Graduate }\end{array}$ & $\begin{array}{c}\text { Bachelor's } \\
\text { Degree }\end{array}$ & $\begin{array}{c}\text { Bachelor's } \\
\text { Degree }\end{array}$ \\
\hline Central City & $\begin{array}{c}0.015 \\
(0.023)\end{array}$ & $\begin{array}{l}-0.007 \\
(0.020)\end{array}$ & $\begin{array}{c}0.093 * * * \\
(0.013)\end{array}$ & $\begin{array}{c}0.079 * * * \\
(0.017)\end{array}$ \\
\hline$M S A$ & $\begin{array}{c}0.041 * * * \\
(0.005)\end{array}$ & $\begin{array}{c}0.059 * * * \\
(0.010)\end{array}$ & $\begin{array}{c}0.073 * * * \\
(0.010)\end{array}$ & $\begin{array}{c}0.089 * * * \\
(0.012)\end{array}$ \\
\hline Male & $\begin{array}{l}-0.007 \\
(0.004)\end{array}$ & $\begin{array}{c}-0.011 * * * \\
(0.003)\end{array}$ & $\begin{array}{c}0.010 * * \\
(0.004)\end{array}$ & $\begin{array}{c}0.012 * * * \\
(0.003)\end{array}$ \\
\hline Nonwhite & $\begin{array}{l}-0.034 \\
(0.028)\end{array}$ & $\begin{array}{l}-0.051 \\
(0.009)\end{array}$ & $\begin{array}{c}-0.073^{* * * *} \\
(0.014)\end{array}$ & $\begin{array}{c}-0.077 * * * \\
(0.010)\end{array}$ \\
\hline Deregulation & $\begin{array}{l}0.015 \\
(0.07)\end{array}$ & $\begin{array}{c}0.004 \\
(0.004)\end{array}$ & $\begin{array}{c}-0.003 \\
(0.023)\end{array}$ & $\begin{array}{c}0.026 * * \\
(0.008)\end{array}$ \\
\hline Constant & $\begin{array}{c}0.804 * * * \\
(0.010)\end{array}$ & $\begin{array}{c}0.855^{* * * *} \\
(0.008)\end{array}$ & $\begin{array}{c}0.151 * * * \\
(0.010)\end{array}$ & $\begin{array}{c}0.133 * * * \\
(0.008)\end{array}$ \\
\hline State Dummies & $\mathrm{X}$ & $\mathrm{X}$ & $\mathrm{X}$ & $\mathrm{X}$ \\
\hline Year Dummies & $X$ & $\mathrm{X}$ & $\mathrm{X}$ & $X$ \\
\hline Age Dummies & $X$ & $X$ & $\mathrm{X}$ & $\mathrm{X}$ \\
\hline Unit Banking States & Yes & No & Yes & No \\
\hline Ages Observed & 20 to 29 & 20 to 29 & 24 to 29 & 24 to 29 \\
\hline Observations & 153407 & 233434 & 95085 & 143052 \\
\hline
\end{tabular}




\begin{tabular}{|c|c|c|c|}
\hline & High School Graduate & College Attendance & Bachelor's Degree \\
\hline Central City & $\begin{array}{l}-0.007 \\
(0.015)\end{array}$ & $\begin{array}{c}0.084 * * * \\
(0.016)\end{array}$ & $\begin{array}{c}0.086 * * * \\
(0.010)\end{array}$ \\
\hline$M S A$ & $\begin{array}{c}0.053 * * * \\
(0.006)\end{array}$ & $\begin{array}{c}0.109 * * * \\
(0.010)\end{array}$ & $\begin{array}{c}0.082 * * * \\
(0.008)\end{array}$ \\
\hline Male & $\begin{array}{c}-0.008 * * * \\
(0.002)\end{array}$ & $\begin{array}{c}0.005 \\
(0.004)\end{array}$ & $\begin{array}{c}0.016 * * * \\
(0.003)\end{array}$ \\
\hline Nonwhite & $\begin{array}{c}-0.048 * * * \\
(0.012)\end{array}$ & $\begin{array}{c}-0.076 * * * \\
(0.015)\end{array}$ & $\begin{array}{c}-0.078 * * * \\
(0.008)\end{array}$ \\
\hline Age at Deregulation: 12 and Under & $\begin{array}{c}0.014 * * \\
(0.06)\end{array}$ & $\begin{array}{c}0.012 \\
(0.015)\end{array}$ & $\begin{array}{c}0.026 * * * \\
(0.012)\end{array}$ \\
\hline Constant & $\begin{array}{c}0.854 * * * \\
(0.005)\end{array}$ & $\begin{array}{c}0.402 * * * \\
(0.010)\end{array}$ & $\begin{array}{c}0.139 * * * \\
(0.008)\end{array}$ \\
\hline State Dummies & $\mathrm{X}$ & $\mathrm{X}$ & $\mathrm{X}$ \\
\hline Year Dummies & $X$ & $\mathrm{X}$ & $\mathrm{X}$ \\
\hline Age Dummies & $\mathrm{X}$ & $\mathrm{X}$ & $\mathrm{X}$ \\
\hline Female or Male & Both & Both & Both \\
\hline White or Nonwhite & Both & Both & Both \\
\hline Ages Observed & 20 to 29 & 20 to 29 & 24 to 29 \\
\hline Observations & 322998 & 322998 & 204543 \\
\hline
\end{tabular}




\begin{tabular}{|c|c|c|c|c|c|c|c|}
\hline & \multicolumn{7}{|c|}{ High school graduate $($ Yes $=1$, No $=0)$} \\
\hline & 1 & 2 & 3 & 4 & 5 & 6 & 7 \\
\hline City & $\begin{array}{l}-0.010 \\
(0.015)\end{array}$ & $\begin{array}{c}-0.009 * * * \\
(0.013)\end{array}$ & $\begin{array}{c}-0.009 \\
(0.015)\end{array}$ & $\begin{array}{l}-0.007 \\
(0.015)\end{array}$ & $\begin{array}{c}-0.001 \\
(0.003)\end{array}$ & $\begin{array}{l}-0.012 \\
(0.016)\end{array}$ & $\begin{array}{c}-0.012 * * * \\
(0.013)\end{array}$ \\
\hline$M S A$ & $\begin{array}{c}0.052^{* * *} * \\
(0.006)\end{array}$ & $\begin{array}{c}0.055^{* * *} * \\
(0.006)\end{array}$ & $\begin{array}{c}0.052 * * * \\
(0.006)\end{array}$ & $\begin{array}{c}0.055^{* * *} * \\
(0.006)\end{array}$ & $\begin{array}{c}0.059^{* * *} \\
(0.007)\end{array}$ & $\begin{array}{c}0.053 * * * \\
(0.006)\end{array}$ & $\begin{array}{c}0.050^{* * *} * \\
(0.005)\end{array}$ \\
\hline Male & $\begin{array}{c}-0.009 * * * \\
(0.002)\end{array}$ & $\begin{array}{c}-0.010 * * * \\
(0.002)\end{array}$ & $\begin{array}{c}-0.009 * * * \\
(0.002)\end{array}$ & $\begin{array}{c}-0.007 * * * \\
(0.002)\end{array}$ & $\begin{array}{c}-0.005^{* *} \\
(0.002)\end{array}$ & $\begin{array}{c}-0.009 * * * \\
(0.002)\end{array}$ & $\begin{array}{c}-0.011 * * * \\
(0.002)\end{array}$ \\
\hline Nonwhite & $\begin{array}{c}-0.045^{* * *} * \\
(0.011)\end{array}$ & $\begin{array}{c}-0.040 * * * \\
(0.010)\end{array}$ & $\begin{array}{c}-0.045^{* * *} \\
(0.011)\end{array}$ & $\begin{array}{c}-0.049 * * * \\
(0.012)\end{array}$ & $\begin{array}{c}-0.056^{* * *} * \\
(0.013)\end{array}$ & $\begin{array}{c}-0.049 * * * \\
(0.011)\end{array}$ & $\begin{array}{c}-0.025 * * * \\
(0.022)\end{array}$ \\
\hline Deregulation & $\begin{array}{c}0.010 * * \\
(0.004)\end{array}$ & $\begin{array}{c}0.010 * * * \\
(0.004)\end{array}$ & $\begin{array}{c}0.010 * * * \\
(0.004)\end{array}$ & $\begin{array}{c}0.010 * * \\
(0.004)\end{array}$ & $\begin{array}{c}0.010 \\
(0.005)\end{array}$ & $\begin{array}{c}0.011 * * \\
(0.005)\end{array}$ & $\begin{array}{c}0.025^{* * *} * \\
(0.010)\end{array}$ \\
\hline Constant & $\begin{array}{c}0.855^{* * *} * \\
(0.005)\end{array}$ & $\begin{array}{c}0.859 * * * \\
(0.000)\end{array}$ & $\begin{array}{c}0.855^{* * *} \\
(0.005)\end{array}$ & $\begin{array}{c}0.853 * * * \\
(0.005)\end{array}$ & $\begin{array}{c}0.851^{* * *} * \\
(0.005)\end{array}$ & $\begin{array}{c}0.857 * * * \\
(0.005)\end{array}$ & $\begin{array}{c}0.853^{* * *} * \\
(0.005)\end{array}$ \\
\hline State Dummies & $\mathrm{X}$ & $X$ & $X$ & $\mathrm{X}$ & $\mathrm{X}$ & $\mathrm{X}$ & $\mathrm{X}$ \\
\hline Year Dummies & $\mathrm{X}$ & $\mathrm{X}$ & $\mathrm{X}$ & $\mathrm{X}$ & $\mathrm{X}$ & $\mathrm{X}$ & $\mathrm{X}$ \\
\hline Age Dummies & $X$ & $X$ & $\mathrm{X}$ & $X$ & $X$ & $\mathrm{X}$ & $X$ \\
\hline $\begin{array}{l}\text { Treatment group age } \\
\text { at deregulation }\end{array}$ & $<18$ & $<18$ & $<17$ & $<18$ & $<18$ & $<18$ & $<18$ \\
\hline Method & LPM & Probit & LPM & LPM & LPM & LPM & LPM \\
\hline Other & None & None & None & $1977-94$ & $1977-89$ & Same state & All States \\
\hline Observations & 386841 & 386841 & 371961 & 327801 & 253708 & 356158 & 524939 \\
\hline $\begin{array}{l}\text { Notes: Standard errors cl } \\
\text { In this table, high school } \\
\text { and the sample of individ } \\
\text { states that deregulated a } \\
\text { specification } 1 \text {. Specifica } \\
\text { Specification } 4 \text { restricts th } \\
6 \text { excludes individuals wh } \\
\text { For specification } 7, \text { the ye }\end{array}$ & $\begin{array}{l}\text { ered by state } \\
\text { duate is the } \\
\text { s from the C } \\
1969 \text {. Spe } \\
\text { n } 3 \text { exclude } \\
\text { ample years } \\
\text { noved to a d } \\
\text { that the add }\end{array}$ & $\begin{array}{l}\text { in parenthesis. } \\
\text { ependent varia } \\
\text { PS March supp } \\
\text { fication } 2 \text { use } \\
\text { individuals a } \\
1977 \text { to } 1994 \\
\text { ferent state in } \\
\text { ional } 11 \text { states }\end{array}$ & $\begin{array}{l}* * \text {, and } * * * \\
\text { le for all spe } \\
\text { lement surve } \\
\text { a probit } \mathrm{m} \\
\text { Sed } 17,18, \\
\text { Specificatio } \\
\text { he past year. } \\
\text { and D.C. der }\end{array}$ & $\begin{array}{l}\text { resent } 5 \text { and } \\
\text { cations. Spe } \\
\text { in years } 19 \\
1 \text { to estima } \\
19 \text { the yea } \\
\text { estricts the } \\
\text { ecification } 7 \\
\text { late is } 1960\end{array}$ & $\begin{array}{l}\text { percent si } \\
\text { fication } 1 \text { u } \\
\text { to } 1999, \text { a } \\
\text { the same } \\
\text { when the s } \\
\text { mple years } \\
\text { ses all state } \\
\text { llowing Le }\end{array}$ & $\begin{array}{l}\text { cance levels } \\
\text { a linear prob } \\
20 \text { to } 29 \text {, an } \\
\text { tion and ob } \\
\text { they live in } \\
77 \text { to } 1989 . \\
\text { d the district } \\
\text { and Rubins }\end{array}$ & $\begin{array}{l}\text { respectively. } \\
\text { ability model } \\
\text { from the } 39 \\
\text { ervations as } \\
\text { deregulated. } \\
\text { Specification } \\
\text { of Columbia. } \\
\text { ein (2013). }\end{array}$ \\
\hline
\end{tabular}


Table 9: High School Graduation, by Race and Gender with False Dates

\begin{tabular}{|c|c|c|c|c|c|}
\hline & \multicolumn{5}{|c|}{ High school graduate $($ Yes $=1$, No $=0)$} \\
\hline & 1 & 2 & 3 & 4 & 5 \\
\hline Central City & $\begin{array}{l}-0.015 \\
(0.014)\end{array}$ & $\begin{array}{l}-0.018 \\
(0.015)\end{array}$ & $\begin{array}{l}-0.023 \\
(0.013)\end{array}$ & $\begin{array}{c}0.011 \\
(0.020)\end{array}$ & $\begin{array}{c}0.011 \\
(0.022)\end{array}$ \\
\hline$M S A$ & $\begin{array}{c}0.044 * * * \\
(0.006)\end{array}$ & $\begin{array}{c}0.039 * * * \\
(0.006)\end{array}$ & $\begin{array}{c}0.039 * * * \\
(0.006)\end{array}$ & $\begin{array}{c}0.071 * * * \\
(0.019)\end{array}$ & $\begin{array}{c}0.076 * * * \\
(0.018)\end{array}$ \\
\hline Male & $\begin{array}{c}-0.010 * * * \\
(0.002)\end{array}$ & & & & \\
\hline Nonwhite & $\begin{array}{l}-0.020 \\
(0.027)\end{array}$ & & & & \\
\hline Deregulation & $\begin{array}{c}0.008 \\
(0.006)\end{array}$ & $\begin{array}{c}0.018 \\
(0.009)\end{array}$ & $\begin{array}{c}0.0011 * * \\
(0.008)\end{array}$ & $\begin{array}{c}0.002 \\
(0.014)\end{array}$ & $\begin{array}{l}-0.009 \\
(0.012)\end{array}$ \\
\hline Constant & $\begin{array}{c}0.866^{* * * *} \\
(0.008)\end{array}$ & $\begin{array}{c}0.863 * * * \\
(0.009)\end{array}$ & $\begin{array}{c}0.887 * * * \\
(0.008)\end{array}$ & $\begin{array}{c}0.829 * * * \\
(0.021)\end{array}$ & $\begin{array}{c}0.675^{* * *} * \\
(0.024)\end{array}$ \\
\hline State Dummies & $\mathrm{X}$ & $\mathrm{X}$ & $\mathrm{X}$ & $\mathrm{X}$ & $\mathrm{X}$ \\
\hline Year Dummies & $\mathrm{X}$ & $\mathrm{X}$ & $\mathrm{X}$ & $\mathrm{X}$ & $\mathrm{X}$ \\
\hline Age Dummies & $\mathrm{X}$ & $\mathrm{X}$ & $\mathrm{X}$ & $\mathrm{X}$ & $\mathrm{X}$ \\
\hline Female or Male & Both & Male & Female & Male & Female \\
\hline Nonwhite or White & Both & White & White & Nonwhite & Nonwhite \\
\hline Ages Observed & 20 to 29 & 20 to 29 & 20 to 29 & 20 to 29 & 20 to 29 \\
\hline Observations & 388426 & 169078 & 176089 & 24897 & 30713 \\
\hline
\end{tabular}


Table 10: False Deregulation Dates, By Year

\begin{tabular}{|c|c|c|c|}
\hline State & Year & State & Year \\
\hline New York & $<1970$ & Nebraska & 1985 \\
\hline North Carolina & $<1970$ & Washington & 1985 \\
\hline Indiana & $<1970$ & West Virginia & 1986 \\
\hline Alaska & $<1970$ & Florida & 1986 \\
\hline Tennessee & $<1970$ & North Dakota & 1987 \\
\hline Oklahoma & $<1970$ & South Carolina & 1987 \\
\hline Missouri & $<1970$ & Texas & 1987 \\
\hline Massachusetts & $<1970$ & Idaho & 1987 \\
\hline Maryland & $<1970$ & Utah & 1987 \\
\hline Oregon & $<1970$ & Rhode Island & 1988 \\
\hline Vermont & $<1970$ & Minnesota & 1988 \\
\hline Louisiana & $<1970$ & Kentucky & 1988 \\
\hline Colorado & 1970 & Arkansas & 1988 \\
\hline New Hampshire & 1975 & California & 1988 \\
\hline New Jersey & 1976 & Hawaii & 1988 \\
\hline Washington D.C. & 1977 & Mississippi & 1989 \\
\hline Maine & 1978 & Ohio & 1990 \\
\hline Connecticut & 1979 & Illinois & 1990 \\
\hline Wisconsin & 1980 & New Mexico & 1990 \\
\hline Iowa & 1981 & Arizona & 1990 \\
\hline Delaware & 1981 & Wyoming & 1991 \\
\hline Alabama & 1982 & Nevada & 1991 \\
\hline Georgia & 1983 & Kansas & 1993 \\
\hline Pennsylvania & 1984 & Virginia & 1994 \\
\hline Michigan & 1985 & Montana & 1999 \\
\hline South Dakota & 1985 & & \\
\hline
\end{tabular}

